\title{
HUBUNGAN STRES KERJA DENGAN KELELAHAN KERJA PADA PEKERJA AREA WORKSHOP KONSTRUKSI BOX TRUCK
}

\author{
THE RELATION BETWEEN WORK STRESS WITH WORK FATIGUE AT \\ WORKSHOP WORKER BOX TRUCK CONSTRUCTION
}

\author{
Augyantantri Dwivira Widyastuti \\ CV. Bumi Lestari Surabaya, Jawa Timur \\ E-mail: dwvraugy@gmail.com
}

\begin{abstract}
PT. Star Queen Indonesia is a company engaged in the field of vehicle manufacture. The number of order box truck construction that received by PT. Star Queen Indonesia and the deadline of the adjacent orders between consumers cause assignment that received by workers was increasing, so workers should take time overtime in the working day with the addition of working hours or holidays such as on Saturday. This can lead to work stress perceived by workers is not small, so workers can experience fatigue. The purpose of this study to analyze the relationship between work stress with work fatigue at workshop workers box truck construction. This research was an observational research with cross sectional approach. Tool used to measure work stress by using stress management questionnaire, and work fatigue using Industrial Fatigue Research Committee (IFRC) questionnaire. The sample of research were workers workshop area of PT. Star Queen Indonesia for 15 people. The results showed that many work stress perceived moderate job stress. This study used chi-square test with $\alpha=0.05$ (5\%) with the result showed there was a relation between work stress and work fatigue (Sig. 2-sided =0.000). The conclusion from this research that there is tendency of relation between work stress and work fatigue, the higher level of work stress perceived by worker then the higher work fatigue at worker
\end{abstract}

Keywords: work stress, work fatigue, box truck construction.

\begin{abstract}
ABSTRAK
PT. Star Queen Indonesia merupakan perusahaan yang bergerak dalam bidang vehicle manufacture. Banyaknya pesanan konstruksi box truck yang diterima oleh PT. Star Queen Indonesia dan deadline pesanan yang berdekatan antar konsumen menyebabkan pekerjaan yang diterima oleh pekerja semakin meningkat, sehingga pekerja harus mengambil waktu lembur baik dalam hari kerja dengan penambahan jam kerja maupun hari libur seperti pada hari sabtu. Hal ini dapat mengakibatkan stres kerja yang dirasakan oleh pekerja tidaklah kecil, sehingga pekerja dapat mengalami kelelahan kerja. Tujuan dari penelitian ini untuk menganalisa hubungan antara stres kerja dengan kelelahan kerja pada pekerja area workshop konstruksi box truck. Penelitian ini merupakan penelitian observasional dengan pendekatan cross sectional. Alat yang digunakan untuk mengukur stres kerja dengan menggunakan kuesioner manajemen stres, dan kelelahan kerja dengan menggunakan kuesioner Industrial Fatigue Research Committee (IFRC). Sampel penelitian adalah pekerja area workshop PT. Star Queen Indonesia sebesar 15 orang. Hasil penelitian menunjukkan bahwa stres kerja yang banyak dirasakan tergolong stres kerja sedang. Penelitian ini menggunakan uji chi-square dengan nilai $\alpha=0,05$ (5\%) dengan hasil menunjukkan ada hubungan antara stres kerja dengan kelelahan kerja (Sig. 2-sided =0,000). Kesimpulan dari penelitian ini bahwa ada kecenderungan hubungan antara stres kerja dan kelelahan kerja, semakin tinggi tingkat stres kerja yang dirasakan oleh pekerja maka semakin tinggi kelelahan kerja pada pekerja.
\end{abstract}

Kata kunci: stres kerja, kelelahan kerja, konstruksi box truck.

\section{PENDAHULUAN}

PT. Star Queen Indonesia merupakan perusahaan yang bergerak di bidang vehicle manufacture atau karoseri kendaraan bermotor. Bisnis utama yang dijalankan oleh PT. Star Queen Indonesia adalah karoseri kendaraan niaga. Adapun contoh produk yang diproduksi oleh PT. Star Queen Indonesia yaitu Aluminium Cargo Box, Steel Cargo Box, Dump Truck, Mobil Toko (MOKO), Double Deck, Wing Box Besi, Wing Box Aluminium, Platform. Bahan utama yang digunakan saat pembuatan produk yaitu aluminium, besi, cat, dan lampu boks. Produk- 
produk tersebut di produksi di area workshop yang dibagi menjadi 3 yaitu area pemotongan, area perakitan, dan area pengecatan. Area workshop PT. Star Queen Indonesia merupakan area terbuka sehingga memiliki lingkungan kerja yang cukup panas dan pekerja memiliki kemungkinan untuk terpapar langsung dengan cahaya matahari.

Lingkungan kerja merupakan keseluruhan dari alat, bahan, kondisi lingkungan tempat kerja, metode kerja, dan pengaturan kerja baik untuk perseorangan maupun kelompok kerja. Lingkungan kerja yang baik terjadi ketika pekerja dapat melaksanakan pekerjaan dengan aman, nyaman, sehat, dan optimal. Sehingga dapat diketahui bahwa kondisi lingkungan kerja yang baik akan meningkatkan kinerja dan produktivitas pekerja (Sedarmayanti, 2001 dalam Lubis, 2015).

Setiap pekerjaan dan lingkungan kerja memiliki potensi risiko bahaya dalam bentuk kecelakaan kerja. Besar potensi kecelakaan tergantung pada jenis produksi, teknologi yang di pakai, bahan yang digunakan, tata ruang, dan lingkungan bangunan, serta kualitas manajemen dan tenaga pelaksana.

Menurut Pusat Data dan Informasi Kesehatan RI (2015), jumlah kasus kecelakaan akibat kerja dari tahun 2011-2014, tahun 2013 memiliki angka kecelakaan kerja yang paling tinggi yaitu 35.917 kasus kecelakaan kerja. Kasus kecelakaan kerja pada tahun 2011 sebanyak 9.891 kasus kecelakaan kerja, pada tahun 2012 sebanyak 21.735 kasus kecelakaan kerja, sedangkan pada tahun 2014 sebanyak 24.910 kasus kecelakaan kerja.

Faktor yang lebih nyata dalam memengaruhi perilaku pekerja merupakan faktor fisik, yaitu tingkat pencahayaan, kebisingan, suhu udara, getaran, pencemaran bahan kimia, penggunaan zat di tempat kerja, serta keindahan yang meliputi musik kerja, warna, dan aroma (Newstrom, 2007 dalam Wulandari, 2012). Iklim kerja adalah bagian faktor fisik yang memengaruhi lingkungan kerja. Menurut International Labour Organizational (2013), lingkungan kerja yang memiliki suhu di bawah atau di atas batas normal, akan berdampak pada perlambatan pekerjaan. Hal ini merupakan respons alami dan fisiologis serta merupakan hal utama yang peting untuk menjaga kestabilan suhu dan kelembapan di tempat kerja. Selain itu, iklim kerja juga berpengaruh terhadap efisiensi dan produktivitas dari pekerja.

Menurut Leka (2008), menyatakan bahwa adanya bahaya yang dapat mengakibatkan stres kerja yaitu konten kerja yang terdiri dari konten

\section{Kasus Kecelakaan Akibat Kerja}

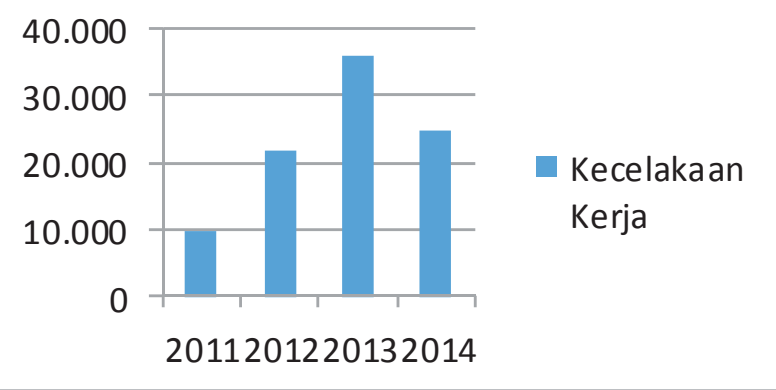

Sumber: Pusat Data dan Informasi Kesehatan RI

Gambar 1. Kasus Kecelakaan Akibat Kerja

tugas, beban kerja, jam kerja, kontrol dan partisipasi, pengembangan karir, jabatan, dan bayaran, tugas dalam organisasi, hubungan interpersonal, dan organisasi kultur. Dalam konten kontrol dan partisipasi terdapat point kurangnya kontrol misalnya dalam lingkungan kerja. Salah satu faktor yang ada di lingkungan kerja yaitu iklim kerja.

Menurut International Labour Organizational (ILO) dalam Halil, dkk (2009), pada Oktober tahun 2000 tentang program dan kebijakan program kejiwaan pada angkatan kerja di beberapa negara yaitu Finlandia, Jerman, Polandia, Inggris, dan Amerika Serikat menunjukkan bahwa stres di tempat kerja atau lingkungan kerja dapat mengakibatkan depresi erat pada pekerja dan meningkatkan kasus gangguan jiwa. Menurut laporan yang ada satu dari sepuluh pekerja mengalami depresi, kecemasan, stres, dan kehilangan semangat. Dalam beberapa kasus hal ini dapat menyebabkan pekerja kehilangan pekerjaan atau dirawat di rumah sakit.

Banyaknya pesanan yang diterima oleh PT. Star Queen Indonesia dan deadline yang berdekatan antar pesanan membuat pekerja harus mengambil waktu lembur, baik dalam hari kerja dengan penambahan jam kerja maupun hari libur seperti pada hari sabtu, dapat membuat pekerja memiliki tingkat stres kerja yang lebih tinggi. Selain itu, setiap kegiatan yang dilakukan oleh pekerja berbeda-beda sesuai dengan proses produksi yang ada di PT. Star Queen Indonesia. Berikut merupakan proses produksi yang ada di PT. Star Queen Indonesia:

Proses produksi PT. Star Queen Indonesia mayoritas masih menggunakan tenaga manusia dalam penyelesaiannya, sehingga ketika pesanan meningkat makan pekerjaan yang dilakukan juga semakin bertambah. 


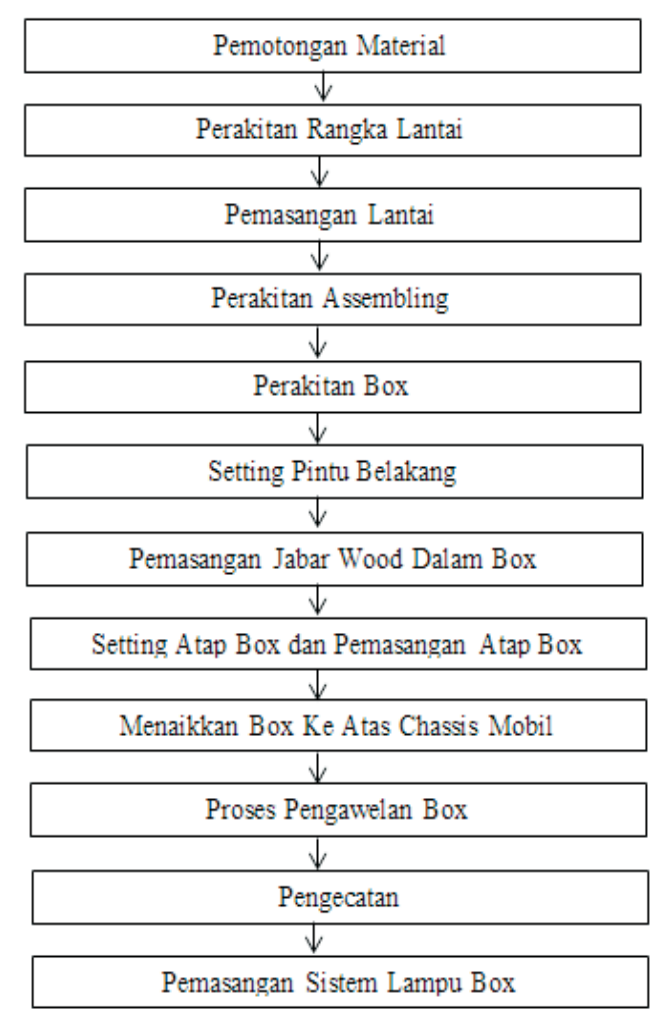

Sumber: PT. Star Queen Indonesia

Gambar 2. Proses Produksi di PT. Star Queen Indonesia

Menurut Tarwaka (2015), stres merupakan tekanan psikologis yang dapat mengakibatkan terjadinya gangguan kesehatan baik secara fisik maupun mental. Menurut hasil survey yang dilakukan oleh European Foundation for the Improvement of Working Condition pada tahun 2000 menentukan bahwa sekitar $28 \%$ pekerja melapor penyakit dan gangguan kesehatan yang diakibatkan oleh stres terutama stres kronis. (Flin, O'Cornor, \& Crihton, 2008 dalam Karima, 2014).

Stres akibat kerja dilaporkan menjadi masalah kedua di Eropa sebagai masalah kesehatan yang berhubungan dengan pekerjaan. Pada tahun 2005 dilaporkan sekitar 22\% dari pekerja di Eropa terkena dampak stres akibat kerja dan sejumlah pekerja lainnya mengalami gangguan yang berhubungan dengan stres akibat pekerjaan (WHO, 2003).

Menurut CDC dalam Karima (2014) menyatakan stres kerja dapat mengakibatkan hilangnya hari kerja akibat kecelakaan kerja dan timbulnya kesakitan. Kerugian yang dialami oleh perusahaan akibat stres kerja juga tidak sedikit. Setiap tahunnya, industri di wilayah Amerika Serikat mengalami kerugian lebih dari US 30 miliar akibat dari kecelakaan, absenteisme, turnover, serta kompensasi asuransi

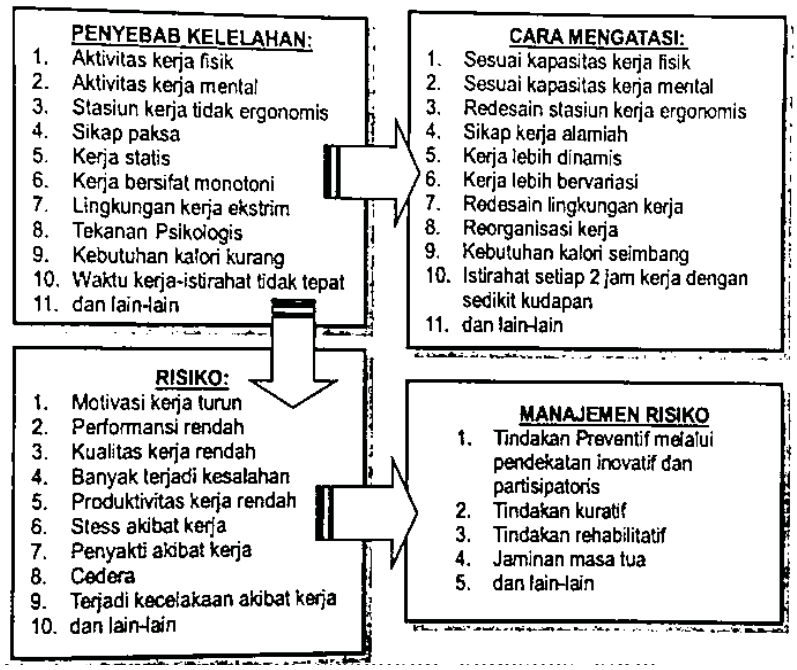

Sumber: Tarwaka, 2015

Gambar 3. Penyebab Kelelahan, Cara Mengatasi, dan Manajemen Risiko Kelelahan

stres kerja yang dialami oleh tenaga kerja (AIS, 2013 dalam Karima, 2014).

Menurut Tarwaka (2015), dampak dari stres akibat kerja dapat menyebabkan reaksi emosional, perubahan kebiasaan atau mental, dan perubahan fisiologis. Salah satu perubahan fisiologis yaitu kelelahan. Stres kerja dapat dikurangi dan dikendalikan melalui dekorasi termasuk dekorasi warna pada area kerja, penggunaan musik saat bekerja, dan memanfaatkan waktu istirahat untuk melakukan latihan fisik yang sesuai bagi tenaga kerja (Suma'mur, 2009).

Panasnya lingkungan kerja yang dirasakan oleh pekerja dan banyaknya pekerjaan dengan deadline yang berdekatan dapat menjadi faktor pemicu terjadinya kelelahan kerja yang dirasakan oleh pekerja area workshop PT. Star Queen Indonesia. Pengambilan waktu lembur baik dalam hari kerja dengan penambahan jam kerja maupun hari libur seperti pada hari sabtu juga dapat menjadi salah satu pemicu pekerja mengalami kelelahan kerja.

Tarwaka (2015), dalam gambar 3 menyebutkan bahwa kelelahan memiliki beberapa penyebab yaitu aktivitas kerja fisik, aktivitas kerja mental, stasiun kerja tidak ergonomis, sikap paksa, kerja statis, kerja bersifat monoton, lingkungan kerja ekstrem, tekanan psikologis, kebutuhan kalori kurang, waktu kerja dan istirahat tidak tepat. Namun kelelahan kerja dapat dihilangkan melalui beberapa cara yaitu memalui penyesuaian kapasitas kerja fisik, penyesuaian kapasitas kerja mental redesain stasiun kerja ergonomi, sikap kerja alamiah, kerja lebih 
dinamis, kerja lebih bervariasi, redesain lingkungan kerja, reorganisasi kerja, kebutuhan kalori seimbang, istirahat setiap 2 jam kerja dengan sedikit kudapan.

Kelelahan kerja juga memiliki beberapa risiko terhadap pekerja, yaitu motivasi kerja menurun, performansi rendah, kualitas kerja rendah, banyak terjadi kesalahan, produktivitas kerja rendah, stres akibat kerja, penyakit akibat kerja (PAK), cedera, kecelakaan kerja. Hal ini dapat dikendalikan melalui manajemen risiko yaitu tindakan preventif melalui pendekatan inovatif dan partisipatoris, tindakan kuratif, tindakan rehabilitatif, jaminan masa tua, dan sebagainya.

Kelelahan kerja menunjukkan perbedaan antara keadaan fisik tubuh dengan mental yang akan mengakibatkan penurunan pada daya kerja dan ketahanan tubuh untuk bekerja akan berkurang. Perasaan lelah yang sangat tinggi akan membuat pekerja tidak mampu lagi melakukan pekerjaannya. Jika terus dipaksakan untuk terus bekerja, kelelahan akan semakin bertambah dan dapat mengganggu kelancaran pekerjaan bahkan dapat memberikan dampak yang buruk bagi kesehatan pekerja (Suma'mur, 2009).

Kelelahan kerja dapat menyebabkan prestasi kerja menjadi menurun, fungsi fisiologis dan neural menjadi menurun, dan semangat kerja menjadi menurun. Kelelahan kerja juga cenderung dapat meningkatkan risiko terjadinya kecelakaan kerja di tempat kerja, sehingga pekerja dan perusahaan dapat dirugikan karena adanya kelelahan kerja ditandai dengan adanya penurunan produktivitas (Glimer, 1996 dan Suma'mur, 1984 dalam Setyawati, 2010). Kelelahan kerja berkontribusi lebih dari $60 \%$ dari semua kecelakaan kerja yang terjadi di tempat kerja (Setyawati, 2010).

Hasil penelitian Hariyono (2009), menunjukkan bahwa adanya hubungan beban kerja, stres kerja, dan tingkat konflik dengan kelelahan kerja pada perawat di Rumah Sakit Islam Yogyakarta PDHI Kota Yogyakarta. Hasil penelitian dari peneliti lain yang berjudul relationship work fatigue related to work stress on circadian rhythm night shift operator employee PT. Indonesia Bulk Terminal Kotabaru, South Kalimantan, Indonesia juga menunjukkan adanya hubungan antara stres kerja yang dirasakan oleh pekerja dengan kelelahan kerja (Sholihah, 2012).

Peneliti lain menyebutkan dalam penelitian yang berjudul Cause and Management Stress at Work bahwa stres kerja dapat disebabkan oleh temperatur lingkungan kerja dan stres kerja dapat menyebabkan respons akut yaitu perasaan kelelahan (Michie, 2002). Peneliti lain menyebutkan adanya hubungan secara bermakna antara stres kerja dengan kelelahan kerja yang dikendalikan oleh umur dan masa kerja (Suleiman, 2014). Peneliti lain yaitu Jacobs, dkk (2015), menunjukkan bahwa adanya hubungan antara stres kerja dengan kelelahan kerja pada karyawan bagian sumber daya manusia di PT. Bank Sulut cabang Manado.

Berdasarkan lingkungan kerja yang panas, banyaknya pesanan yang ada, dan waktu penyelesaian (deadline) pembuatan produk yang berdekatan antar pesanan di PT. Star Queen Indonesia, maka penelitian ini bertujuan untuk menganalisis hubungan antara stres kerja dengan kelelahan kerja pada pekerja area workshop PT. Star Queen Indonesia.

Dengan demikian diharapkan setelah dilakukannya penelitian ini dapat diketahui keadaan tingkat stres kerja dan tingkat kelelahan kerja pada pekerja area workshop PT. Star Queen Indonesia yang selanjutnya dapat dijadikan sumber informasi bagi perusahaan untuk melakukan pengendalian. Selain itu, juga dapat dijadikan informasi untuk para pekerja sehingga dapat menambah wawasan mengenai stres kerja dan kelelahan kerja.

\section{METODE}

Penelitian ini adalah penelitian observasional. Penelitian ini merupakan penelitian analitik karena penelitian ini bertujuan untuk mencari hubungan sebab akibat dalam dua kelompok yang berbeda. Studi penelitian dilakukan dengan cara cross sectional yaitu data diambil dalam dimensi ruang dan waktu yang sama.

Penelitian dilakukan di PT. Star Queen Indonesia. Waktu penelitian dilaksanakan pada April 2017. Data primer didapatkan dengan pengukuran, penyebaran kuesioner, dan wawancara, sedangkan data sekunder didapatkan dari wawancara dan observasi. Responden dalam penelitian ini adalah pekerja area workshop PT. Star Queen Indonesia sejumlah 15 orang.

Variabel dependen dalam penelitian ini adalah kelelahan kerja yang akan diukur menggunakan kuesioner Industrial Fatigue Research Committee (IFRC). Sedangkan, variabel independen dalam penelitian ini adalah stres kerja yang akan diukur menggunakan kuesioner manajemen stres.

Data hasil penelitian yang telah diperoleh di lapangan akan dikumpulkan dan diolah untuk 
mengetahui hubungan antara variabel disajikan ke dalam bentuk tabel tabulasi silang. Analisis statistik menggunakan uji Chi-Square.

\section{HASIL}

\section{Stres Kerja}

Pengukuran stres kerja dalam penelitian ini menggunakan metode kuesioner yang selanjutnya data dari kuesioner akan dikategorikan menjadi 3 kelompok yaitu stres kerja ringan, stres kerja sedang, dan stres kerja berat. Tabel 1 merupakan distribusi stres kerja yang dialami oleh masing-masing tenaga kerja di area workshop PT. Star Queen Indonesia.

Berdasarkan tabel 1 dapat diketahui bahwa stres kerja yang paling banyak diterima oleh responden yaitu stres kerja sedang sebanyak 9 orang responden atau sebesar $60 \%$ dari total responden. Sedangkan 1 orang responden atau sebesar $6,67 \%$ dari total responden memiliki stres kerja ringan dan sisanya sebanyak 5 orang responden atau sebesar 33,33\% dari total responden memiliki stres kerja berat.

\section{Kelelahan Kerja}

Pengukuran kelelahan kerja pada penelitian ini menggunakan metode kuesioner Industrial Fatigue Research Committee (IFRC), selanjutnya data yang telah terkumpul dari kuesioner akan dikategorikan

Tabel 1. Distribusi Responden Berdasarkan Stres Kerja Pada Pekerja Area Workshop PT. Star Queen Indonesia, Mei 2017

\begin{tabular}{ccc}
\hline Stres Kerja & Jumlah (orang) & Persentase (\%) \\
\hline Ringan & 1 & 6,67 \\
Sedang & 9 & 60 \\
Berat & 5 & 33,33 \\
\hline Total & 15 & 100 \\
\hline
\end{tabular}

menjadi 3 kelompok yaitu kelelahan kerja ringan, kelelahan kerja sedang, kelelahan kerja berat. Tabel 2 merupakan distribusi kelelahan kerja yang dialami oleh masing-masing tenaga kerja di area workshop PT. Star Queen Indonesia.

Berdasarkan tabel 2 dapat diketahui bahwa sebanyak 7 orang responden atau sebesar $46,67 \%$ dari total responden sama-sama memiliki kelelahan kerja sedang dan kelelahan kerja tinggi. Sedangkan 1 orang responden atau sebesar $6,67 \%$ dari total responden memiliki beban kerja ringan.

\section{Hubungan Stres Kerja dengan Kelelahan Kerja}

Berdasarkan data penelitian, stres kerja dikategorikan menjadi 3 kelompok, yaitu beban kerja rendah, beban kerja sedang, dan beban kerja tinggi, dan kelelahan kerja dikategorikan menjadi kelelahan kerja ringan, kelelahan kerja sedang, kelelahan kerja tinggi, dan kelelahan kerja sangat tinggi. Untuk mengetahui hubungan antara stres kerja dan kelelahan kerja digunakan uji chi-square dengan nilai $\alpha=0,05(5 \%)$. Tabel 3 merupakan hubungan stres kerja dengan kelelahan kerja di area workshop PT. Star Queen Indonesia.

Berdasarkan tabel 3 dapat diketahui bahwa pekerja yang mengalami beban kerja tingkat ringan

Tabel 2. Distribusi Responden Berdasarkan Kelelahan Kerja pada Pekerja Area Workshop PT. Star Queen Indonesia, Mei 2017

\begin{tabular}{ccc}
\hline Kelelahan Kerja & $\begin{array}{c}\text { Jumlah } \\
\text { (orang) }\end{array}$ & $\begin{array}{c}\text { Persentase } \\
(\%)\end{array}$ \\
\hline Ringan & 1 & 6,67 \\
Sedang & 7 & 46,47 \\
Tinggi & 7 & 46,67 \\
Sangat Tinggi & 0 & 0 \\
\hline Total & 15 & 100 \\
\hline
\end{tabular}

Tabel 3. Hubungan Stres Kerja dengan Kelelahan Kerja pada Pekerja Area Workshop PT. Star Queen Indonesia, Mei 2017

\begin{tabular}{|c|c|c|c|c|c|c|c|c|c|c|c|}
\hline \multirow{3}{*}{ Stres Kerja } & \multicolumn{8}{|c|}{ Kelelahan Kerja } & \multirow{2}{*}{\multicolumn{2}{|c|}{ Total }} & \multirow{3}{*}{$\begin{array}{c}\text { Asymp. Sig } \\
\text { (2-sided) }\end{array}$} \\
\hline & \multicolumn{2}{|c|}{ Ringan } & \multicolumn{2}{|c|}{ Sedang } & \multicolumn{2}{|c|}{ Tinggi } & \multicolumn{2}{|c|}{ Sangat Tinggi } & & & \\
\hline & n & $\%$ & $\mathbf{n}$ & $\%$ & n & $\%$ & n & $\%$ & $\mathbf{N}$ & $\%$ & \\
\hline Ringan & 1 & 6,7 & 0 & 0 & 0 & 0 & 0 & 0 & 1 & 6,7 & \multirow{4}{*}{0,000} \\
\hline Sedang & 0 & 0 & 7 & 46,7 & 2 & 13,3 & 0 & 0 & 9 & 60 & \\
\hline Berat & 0 & 0 & 0 & 0 & 5 & 33,3 & 0 & 0 & 5 & 33,3 & \\
\hline Total & 1 & 6,7 & 7 & 46,7 & 7 & 46,7 & 0 & 0 & 15 & 100 & \\
\hline
\end{tabular}


dengan kelelahan kerja tingkat ringan sebesar 6,7\% atau sebanyak 1 orang responden. Pekerja yang mengalami beban kerja tingkat sedang dengan kelelahan kerja tingkat sedang sebesar $46,7 \%$ atau sebanyak 7 orang responden, sedangkan pekerja yang mengalami stres kerja tingkat sedang dengan kelelahan kerja tingkat tinggi sebesar 13,3\% atau sebanyak 2 orang responden. Serta pekerja yang mengalami stres kerja tingkat berat dengan kelelahan kerja tingkat berat sebesar 33,3\% atau sebanyak 5 orang responden.

Berdasarkan analisis uji chi-square dengan nilai $\alpha=0,05$ (5\%) didapatkan hasil Sig. (2-sided) $=0,000$. Nilai Sig. $(2$-sided $)=0,003<\alpha=0,05$ sehingga jika dilihat dari nilai sig. dan nilai $\alpha$ maka dapat disimpulkan bahwa ada hubungan antara stres kerja dengan kelelahan kerja.

\section{PEMBAHASAN}

\section{Stres Kerja}

Peneliti mengukur stres kerja pada pekerja area workshop PT. Star Queen Indonesia dengan menggunakan kuesioner stres kerja yaitu manajemen stres dengan metode skoring. Dari hasil pengisian kuesioner yang telah diisi oleh pekerja area workshop PT. Star Queen Indonesia, selanjutnya akan dihitung total skornya dan kemudian akan dikategorikan menjadi 3 kelompok yaitu stres kerja tingkat ringan, stres kerja tingkat sedang, dan stres kerja tingkat berat. Berdasarkan hasil penelitian dari 15 pekerja area workshop PT. Star Queen Indonesia dapat diketahui bahwa pekerja mengalami stres kerja ringan dengan persentase $6,67 \%$ atau sebanyak 1 orang, stres kerja sedang dengan persentase $60 \%$ atau sebanyak 9 orang, dan stres kerja berat dengan persentase 33,33\% atau sebanyak 5 orang.

Berdasarkan hasil penelitian dapat dilihat bahwa ada beberapa pekerja yang mengalami stres kerja berat, namun sebagian besar dari pekerja mengalami stres kerja sedang. Hal ini disebabkan karena setiap pekerja memiliki jenis pekerjaan yang berbeda satu sama lain sesuai dengan proses produksi yang ada di PT. Star Queen Indonesia mulai dari proses pemotongan bahan baku hingga proses pengecatan box truck yang telah selesai diproduksi sampai proses pemasangan lampu pada box. Selain itu, setiap kegiatan yang dilakukan dalam proses produksi mayoritas masih menggunakan tenaga manusia dalam penyelesaiannya, sehingga ketika pesanan meningkat makan pekerjaan yang dilakukan juga semakin bertambah.
Pada saat bekerja para pekerja melakukan pekerjaannya diselingi dengan percakapan ringan sesama pekerja dan mendengarkan musik kerja yang dipasang dari salah satu handphone yang dimiliki oleh pekerja secara bergantian. Namun, tidak semua pekerja dapat mendengarkan musik yang dipasang karena area workshop yang cukup luas dan terbuka sehingga suara musik dari handphone yang dimiliki pekerja tidak dapat terdengar di seluruh bagian workshop, hanya bagian yang dekat dengan letak handphone yang sedang memasang musik kerja.

Berdasarkan pembahasan di atas, maka dapat disimpulkan bahwa sebagian besar pekerja area workshop PT. Star Queen Indonesia yang mengalami tingkat stres kerja berat dan tingkat stres kerja sedang yang perlu dilakukan tindakan perbaikan agar tidak mengalami risiko kelelahan kerja. Menurut Tarwaka (2015), terdapat beberapa dampak yang disebabkan akibat stres kerja yaitu reaksi emosional, perubahan kebiasaan atau mental, perubahan fisiologis, performansi kerja menurun, kualitas kerja menurun, absensi pekerja meningkat, dan hubungan kerja menjadi tegang. Menurut Arden (2006) dalam Nugrahani (2008), gejala yang ditimbulkan dari stres kerja yaitu gejala fisik contohnya sakit kepala dan bahu tegang, gejala psikologis contohnya mudah lupa dan kurang konsentrasi, serta gejala perilaku contohnya mudah marah dan mudah tersinggung.

\section{Kelelahan Kerja}

Dari penelitian ini, peneliti mengukur kelelahan kerja yang dilakukan pada pekerja area workshop PT. Star Queen Indonesia dengan menggunakan kuesioner Industrial Fatigue Research Committee (IFRC) dengan metode skoring. Hasil pengisian kuesioner yang telah diisi oleh pekerja area workshop PT. Star Queen Indonesia selanjutnya akan dihitung total skornya dan dikategorikan menjadi 4 kelompok yaitu kelelahan kerja tingkat ringan, kelelahan kerja tingkat sedang, kelelahan kerja tingkat tinggi, dan kelelahan kerja tingkat sangat tinggi. Berdasarkan hasil penelitian pada 15 pekerja area workshop PT. Star Queen Indonesia dapat diketahui bahwa pekerja yang mengalami kelelahan kerja ringan dengan persentase sebesar $6,67 \%$ atau sebanyak 1 orang, kelelahan kerja sedang dengan persentase sebesar $46,67 \%$ atau sebanyak 7 orang, dan kelelahan kerja tinggi dengan persentase sebesar $46,67 \%$ atau sebanyak 7 orang. Tidak terdapat pekerja yang mengalami kelelahan kerja sangat tinggi pada pekerja area workshop PT. Star Queen Indonesia. 
Kelelahan kerja berat yang dialami oleh pekerja area workshop PT. Star Queen Indonesia dikarenakan banyak nya pesanan yang datang dari beberapa pelanggan untuk membuat box truck untuk kendaraan bermotor dengan jenis yang berbeda beda dengan deadline waktu penyelesaian produk yang berdekatan dari tiap pelanggan. Hal ini menyebabkan pekerja area workshop PT. Star Queen Indonesia harus mengambil waktu lembur agar produksi konstruksi box truck yang dipesan oleh pelanggan dapat terselesaikan tepat waktu mengingat waktu untuk membuat satu konstruksi box truck tidaklah sebentar dan tenaga yang digunakan juga cukup besar. Sehingga ketika pekerja mengambil waktu lembur tenaga yang dibutuhkan juga semakin besar.

Kelelahan pekerja juga dapat disebabkan oleh proses produksi yang dijalankan sebagian besar dikerjakan oleh tenaga manusia membuat pekerja juga dapat merasakan kelelahan kerja. Ditambah lagi lingkungan kerja yang memiliki iklim kerja area workshop PT. Star Queen Indonesia yang cukup panas merupakan beban tambahan yang dirasakan oleh pekerja. Hal ini juga dapat meningkatkan perasaan kelelahan pada pekerja.

Menurut Setyawati (2010), kelelahan kerja berkontribusi lebih dari $60 \%$ terhadap terjadinya kecelakaan kerja. Selain itu, menurut Glimer (1996) dan Suma'mur (1984) dalam Setyawati (2010), kelelahan kerja dapat menyebabkan prestasi kerja menjadi menurun, fungsi fisiologis dan neural menjadi menurun, dan semangat kerja menjadi menurun. Kelelahan kerja juga cenderung dapat meningkatkan risiko terjadinya kecelakaan kerja di tempat kerja, sehingga pekerja dan perusahaan dapat dirugikan karena adanya kelelahan kerja ditandai dengan adanya penurunan produktivitas.

Menurut Grandjean (1995) dalam Setyawati (2010), kelelahan kerja memiliki gejala yaitu tidak ada gairah kerja, sulit berpikir, penurunan kesiagaan, penurunan persepsi, dan penurunan reaksi kerja. Menurut Suma'mur (2009), kelelahan kerja memiliki beberapa gejala seperti perasaan berat di kepala, pikiran terasa kacau, sulit berpikir, sering lupa, tidak dapat berkonsentrasi, sakit kepala, bahu terasa kaku, tidak dapat mengendalikan emosi. Kelelahan kerja dapat diatasi dengan beberapa cara menurut Tarwaka (2015), diantaranya melalui sikap kerja secara alamiah, kerja lebih bervariasi, redesain lingkungan kerja, kebutuhan kalori seimbang, istirahat selama 2 jam kerja dengan sedikit kudapan.

\section{Hubungan Stres Kerja dengan Kelelahan Kerja}

Berdasarkan hasil penelitian dapat diketahui bahwa pekerja yang mengalami stres kerja tingkat ringan dengan kelelahan kerja ringan dengan persentase sebesar $6,7 \%$ atau sebanyak 1 orang. Hal ini disebabkan oleh jenis pekerjaan yang berbeda antar pekerja sehingga untuk salah satu pekerja stres kerja yang dirasakan tidak terlalu tinggi, namun tetap berpengaruh terhadap kelelahan kerja meskipun hanya sedikit. Hal ini dapat terjadi pada pekerja area workshop yang mendapatkan pekerjaan yang tidak terlalu berat.

Sebaliknya pekerja yang mengalami stres kerja tingkat sedang dengan kelelahan kerja sedang dengan persentase $46,7 \%$ atau sebanyak 7 orang serta pekerja yang mengalami stres kerja tingkat sedang dengan kelelahan kerja tinggi dengan persentase $13,3 \%$ atau sebanyak 2 orang serta pekerja yang mengalami stres kerja tingkat tinggi dengan kelelahan kerja tinggi dengan persentase $33,3 \%$ atau sebanyak 5 orang. Hal ini dikarenakan semakin tinggi stres kerja maka dapat memengaruhi kelelahan kerja sehingga kelelahan kerja yang dialami akan semakin tinggi. Selain itu stres kerja juga dapat dipengaruhi oleh faktor luar pekerjaan seperti masalah di luar kantor. Selain itu, banyaknya pesanan konstruksi box truck yang harus diselesaikan dengan deadline yang berdekatan antar pesanan membuat pekerja harus mengambil waktu lembur, baik dalam hari kerja dengan penambahan jam kerja maupun hari libur seperti pada hari sabtu, membuat waktu kerja pada pekerja bertambah untuk menyelesaikan pekerjaan tersebut. Hal ini menyebabkan kelelahan pekerja juga dapat meningkat.

Menurut Tarwaka (2015), stres kerja dapat menyebabkan beberapa dampak terhadap pekerja, salah satunya adalah dampak perubahan fisiologi. Dimana perubahan fisiologi salah satunya adalah kelelahan yang dirasakan oleh pekerja. Hal ini diperkuat dengan adanya penelitian yang dilakukan oleh Jacobs, dkk (2015), hasil penelitiannya menunjukkan bahwa adanya hubungan antara stres kerja dengan kelelahan kerja. Dalam penelitian yang dilakukan Jacobs, dkk (2015), pada karyawan bagian sumber daya PT. Bank Sulut cabang Manado didapatkan hasil responden terkadang merasa tegang dan sakit otot terutama pada leher, bahu dan pinggang, meskipun tidak ada riwayat trauma.

Dalam Penelitian lain yaitu Sholihah dan Rahmi (2012), juga menunjukkan adanya hubungan antara stres kerja yang dirasakan oleh pekerja dengan 
kelelahan kerja pada operator shift malam PT. Indonesia Bulk Terminal Kotabaru, Kalimantan Selatan. Hasil penelitiannya menyebutkan bahwa stres kerja berbanding lurus dengan kelelahan kerja dan juga dipengaruhi oleh faktor-faktor lain di tempat kerja yaitu kebisingan yang tinggi, panas, hubungan dengan keluarga, tingginya tingkat ekonomi di tempat kerja, hubungan di tempat kerja, dan tuntutan fisik yang ada di tempat kerja merupakan bahaya risiko yang dapat meningkatkan stres kerja. Hal ini dapat didukung dengan adanya penelitian dari (Michie, 2002) yang menyebutkan dalam penelitian yang berjudul Cause and Management Stress at Work bahwa stres kerja dapat disebabkan oleh temperatur lingkungan kerja dan stres kerja dapat menyebabkan respons akut yaitu perasaan kelelahan.

Peneliti lain Hariyono, dkk (2009), juga menunjukkan hasil yang sama dari penelitiannya yaitu menunjukkan bahwa adanya hubungan beban kerja, stres kerja, dan tingkat konflik dengan kelelahan kerja pada perawat di Rumah Sakit Islam Yogyakarta PDHI Kota Yogyakarta. Hasil penelitian menunjukkan bahwa adanya beberapa faktor yang dapat memengaruhi terjadinya stres kerja pada perawat Rumah Sakit Islam Yogyakarta PDHI yaitu pertama, kondisi pekerjaan dimana beban kerja yang berlebihan secara kualitatif dan kuantitatif dan dapat meningkatkan ketegangan dan kelelahan mental dan atau fisik. Kedua, faktor interpersonal yang dapat menyebabkan hasil kerja menurun, dukungan sosial buruk, persaingan tidak sehat, dan kecemburuan sosial. Ketiga, masalah pekerjaan yang dicampuradukkan dengan masalah pribadi, kurangnya dukungan dari pasangan hidup, dan stres memiliki dua pekerjaan. Hal ini dapat memicu terjadinya kelelahan secara mental.

Peneliti lain menyebutkan adanya hubungan secara bermakna antara stres kerja dengan kelelahan kerja yang dikendalikan oleh umur, adanya hubungan secara bermakna antara stres kerja dengan kelelahan kerja yang dikendalikan masa kerja, dan adanya hubungan secara bermakna antara stres kerja dengan kelelahan kerja yang dikendalikan oleh umur dan masa kerja (Suleiman, 2014).

\section{SIMPULAN}

Kesimpulan dari penelitian ini yaitu stres kerja yang paling banyak diterima oleh pekerja area workshop konstruksi box truck yaitu stres kerja sedang dengan kelelahan kerja sedang sebanyak 7 orang atau sebesar $46,7 \%$, sehingga ada kecenderungan hubungan antara stres kerja dan kelelahan kerja, semakin tinggi stres kerja yang dirasakan oleh pekerja maka semakin tinggi juga kelelahan kerja pada pekerja.

Berdasarkan kesimpulan yang ada dapat di berikan saran kepada perusahaan untuk menyediakan selingan waktu disela-sela jam kerja (coffee break) untuk para pekerja mengembalikan energi dengan memberikan kudapan, menyediakan air minum yang cukup sesuai kebutuhan pekerja, dan memberikan musik kerja yang digemari oleh pekerja. Sedangkan untuk para pekerja sebaiknya pekerja mengonsumsi air minum minimal 1 gelas $(150-200 \mathrm{cc})$ selama 15-20 menit sekali.

\section{DAFTAR PUSTAKA}

International Labor Organization (ILO). 2013. Keselamatan dan Kesehatan Kerja di Tempat Kerja, Sarana untuk Produktivitas. Jakarta.

Halil, I.S., Russeng., Syamsiar., Saleh, L.M. 2009. Stress Kerja pada Operator Mesin Pembangkit Listrik di PT. PLN (Persero) Sektor Tello Makassar. Jurnal MKMI, Volume 5 No. 3, Juli 2009, hal 25-31.

Hariyono, W., Suryani, D., Wulandari, Y. 2009. Hubungan antara Beban Kerja, Stres Kerja, dan Tingkat Konflik dengan Kelelahan Kerja Perawat di Rumah Sakit Islam Yogyakarta PDHI Kota Yogtyakarta. Jurnal KESMAS: Volume 3, No. 3, September 2009, Hal. 186-197.

Jacobs, B.W.P., Kawatu, P.A.T., Maramis F.R.R., Rattu, A.J.M. 2015. Hubungan antara Stres Kerja dengan Kelelahan Kerja pada Karyawan Bagian Sumber Daya Manusia di PT. Bank Sulut Cabang Manado. Jurnal Administrasi Publik, Volume 4, Nomer 32 (sitasi : 12 Juni 2017,https://ejournal. unsrat.ac.id/index.php/JAP/article/view/10377).

Karima, A. 2014. Faktor-faktor yang Berhubungan dengan Stress Kerja pada Pekerja Di PT. X Tahun 2014. Skripsi. Universitas Islam Negeri (UIN) Syarif Hidayatullah Jakarta.

Michie, S. 2002. Causes and Management of Stress at Work. Journal Occupational and Environmental Medicine, Volume 59, Issue $1: 67-72$.

Nugrahani, S. 2008. Faktor-faktor yang Berhubungan dengan Stres Kerja pada Pekerja Bagian Operasional PT. Gunze Indonesia. Skripsi. Universitas Indonesia. 
Peraturan Menteri Tenaga Kerja dan Transmigrasi Republik Indonesia No. Per.13/MEN/X/2011 Tentang Nilai Ambang Batas Faktor Fisika dan Faktor Kimia di Tempat Kerja. Jakarta: Kementerian Tenaga Kerja dan Transmigrasi.

Pusat Data dan Informasi Kementerian Kesehatan RI. 2015. Situasi Kesehatan Kerja. Jakarta: Kementerian Kesehatan RI.

Setyawati, L.K.M. 2010. Sekilas tentang Kelelahan Kerja. Yogyakarta: Amara Books.

Sholihah, Q., Fauziah, R. 2013. Relationship Work Fatigue Related to Work Stress on Circadian Rhythm Night Shift Operator Employee PT. Indonesia Bulk Terminal Kotabaru, South Kalimantan, Indonesia. The European Journal of Social \& Behavioural Science, Volume . IX, Page. 1410-1416 (Sitasi: 12 Juni, http:// www.futureacademy.org.uk/files/menu_items/ other/125.pdf).

Suleiman, R. 2014. Hubungan antara Stres Kerja dengan Kelelahan Kerja yang Dikendalikan Umur dan Masa Kerja pada Perawat Rumah
Sakit Swasta X di Yogyakarta. Tesis. Yogyakarta: Universitas Gajah Mada.

Suma'mur, P.K. 2009. Higiene Perusahaan dan Kesehatan Kerja. Jakarta: CV Sagung Seto.

Tarwaka. 2015. Ergonomi Industri (Dasar-dasar Pengetahuan Ergonomi dan Aplikasi di Tempat Kerja). Surakarta: Harapan Press.

Leka, S. 2004. Protecting Workers' Health Series No. 3 Work Organization \& Stress. WHO Library Cataloguing-in-Publication Data. Tersedia di: www.who.int/occupational_health/publications/ pwh3rev.pdf [diakses tanggal 02 November 2016].

Lubis, A. 2015. Lingkungan Kerja yang Kondusif dan Faktor yang Memengaruhinya. Jurnal AlMasharif: Volume 3, No. 1, Januari-Juni 2015.

WHO. 2003. Work Organization and Stress. United Kingdom: WHO.

Wulandari, A.P.J. 2012. Hubungan antara Lingkungan Kerja Fisik (Temperatur, Dekorasi, dan Musik) dengan Semangat Kerja Karyawan di MNC Promo. Skripsi. Jakarta: Universitas Bina Nusantara. 